\title{
MENOLAK BANKRUT: USAHA UMKM BERADAPTASI DALAM PASAR ONLINE
}

\author{
Asmuni \\ Program Studi Ilmu Administrasi Negara \\ STIA Pembangunan Jember \\ Email : asmuni.mumun01@gmail.com
}

\begin{abstract}
ABSTRAK
Tulisan ini mengulas tentang usaha UMKM di desa binaan beradaptasi dengan kecanggihan teknologi. Ketertinggalan pelaku UMKM dalam menanfaatkan kemajuan teknolgi, membuat usaha mereka jalan ditempat. Melibatkan mitra pengabdian yaitu kelompok UMKM di desa Jatisari Kecamatan Jenggawa Kabupaten Jember Provinsi Jawa Timur Indonesia.

Kelompok UMKM ini sengaja diintervensi untuk berhimpun dalam menghadapi tantangan pasar online. Pengabdian pada masyarakat ini, difokuskan kepada pemahaman dan membangun kesadaran dari pelaku UMKM akan pentingnya pemanfaat dunia digital bagi kemajuan usaha yang dijalankan. Hasil pengabdian terdiri dari tiga aktivitas yaitu transfer pengetahuan tentang dunia digital dewasa ini, pemberian pemahaman tentang peluang usaha melalui pasar online, regestrasi lapak online bagi UMKM di desa binaan.
\end{abstract}

Kata kunci: UMKM, Desa Binaan, Pasar Online 


\section{Analisis Situasi}

Ketergantungan internet yang hampir tak terbendung, ternyata ada kelompok yang masih gamang dengan fenomena tersebut. Sebuah fakta bahwa ada sebagian pelaku Usaha Mikro Kecil dan Menengah (UMKM) yang gamang dengan era internet terkesan membuatprogram pengabdian kepada masyarakat ini menjadi para pelaku usaha UMKM model ini sebagai mitra. Singkatnya mitra dari pengabdian masyarakat ini adalah UMKM yang belum mempunyai lapak dipasar online.

Mengapa pelaku UMKM yang belum punya lapak online? Karena ada situasi pelaku UMKM model ini harus digerakkan. Sikap pasif pelaku UMKM ini dalam menyongsong perkembangan internet dan pemanfatan pasar online cukup menghawatirkan ketika diperbandingkan dengan perubuhan pelaku usaha (bisa UMKM, pelaku usaha lain dalam memanfaatkan cepat teknologi. Secara umum, sasaran mitra ini bukanlah pihak melakukan inisiatif terhadap perkembangan teknologi. Pelaku UMKM secara umum adalah pengikut dari aplikasi yang berbasis teknologi.

Disisi lain, di dunia lain, para pelaku usaha lain telah terbiasa dengan kecanggihan intenet. Syarat kemajuan bagi pelaku usaha model ini adalah berbasis teknologi. Generasi baru ini merupaka pelopor. Dan generasi baru ini meninggalkan pelaku usaha generasi usaha sebelumnya termasuk UMKM yang telah establis. Generasi baru ini, bukan hanya penguasa panggung bisnis online. Lebih jauh, generasi ini terus berinovasi sehingga mampu membagun bisnis online yang tak biasa. Yaitu era strat up dan era unicorn. Di Indonesia, generasi ini pemegang kendali bisnis online. Berikut gambar grafik pemilik akun waru laba paling berhasil di Indonesia. 


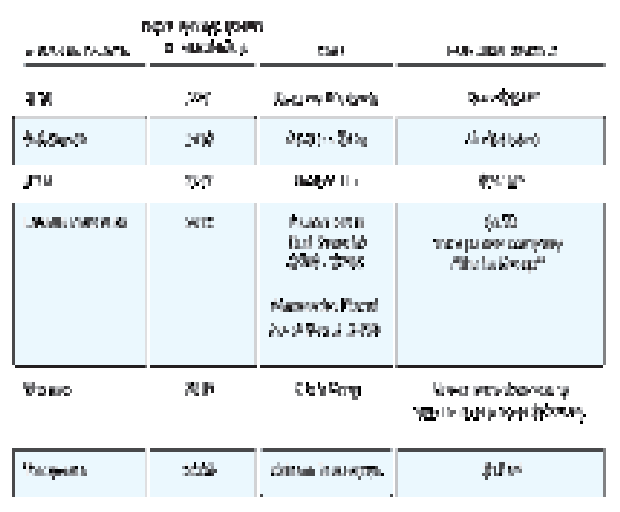

Sumber data:

https://dailysocial.id/post/eecommerce-di-indonesia-2018

Gambar diatas dapat diartikan bahwa era bisnis konvensional telah mengalami dispresi yang luar biasa. Perlu digaris bawahi, produk-produk yang laris saat ini telah mengunakan template berbasis aplikasis teknologi. Ini menjadi mempunyai alasan yang sangat kuat mengingat pesatnya pertumbuhan pengguna online di dunia termasuk di Indonesia. Berdasarkan data yang ada, pengguna dunia maya sangat banyak yaitu mencapai $50 \%$ lebih dari penduduk Indonesia. Terlebih penggunaan media sosial. Berikut gambar grafik penggunaan media sosial.

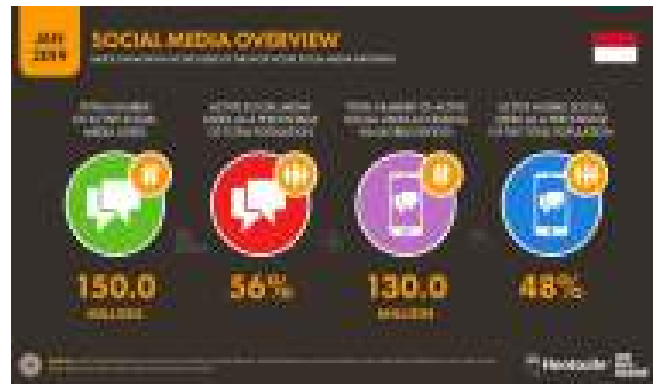

Sumber: Hootsuite diakses melalui https://datareportal.com/reports/digit al-2019-indonesia

Maraknya pengguna internet selanjutya juga memaksa dunia binsis beradaptasi. Adanya fakta bahwa bisnis melalui intenet atau lebih dikenal dengan bisnis online di Indonesia mempunyai pangsa pasar yang sangat cerah. Selain banyak pelaku yang aktif melakukan kreativitas, pengguna internet yang melakukan transaksi terus meningkat. Rata-rata penjualan online di Indonesia mencapai US\$1,1 miliar Menariknya, peningkatan pembelajan online terjadi, salah satunya disebabkan berkembangnya jumlah pengusaha dan pelaku UMKM di tanah air.(www.wartaekonomi.co.id/read2 $\underline{16302 /)}$. 
Terlepas usaha masif dalam beberapa tahun terakhir ini untuk melibatkan UMKM. Dalam skala tertentu, pelaku UMKM masih belum mengerti dan memahami apa dan bagaimana pengaruh transaksi online terhadap keberlangsungan usaha. Tulisan pengabdian kepada masyarakat, melihat adanya gap bahwa masih ada UMKM dari hampir semua aspek berada masih belum terbiasa dengan penggunaan teknologi. Aspek tersebut bisa ditelusuri dari produksi sampai pemasaran masih konvensional. Kedua, keberadaan UMKM yang kurang tersentuh ini secara umum berada di pedesaan dengan kualitas SDM berpendidikan rendah tetapi memiliki usaha di sektor UMKM. Ketiga, ketertinggalan ini menjadi mata rantai kemiskinan masyarakat, dan hal tersebut memerlukan solusi pemecahan masalah.

Untuk memperoleh gambaran menyeluruh, tulisan dimulai dari analisis situasi dan latarbelakang, landasan teori terdiri dari empat bagian. Setelah itu, identifikasi dan perumasan masalah, tujuan kegiatan, kerangka pemecahan masalah (diskusi), khalayak sasaran, metode kegiatan dan evaluasi kegiatan berupa knowledgement.

\section{Landasan Teori}

Landasan teori digunakan untuk landasan kegiatan dan stoke knowledge bagi semua pihak, khususnya bagi kelompok mitra. Berikut empat bagian landasan teori; A. Usaha Mikro Kecil dan Menengah (UMKM)

Usaha mikro kecil dan menengah (UMKM) merupakan entitas yang berbeda dengan kebanyak bisnis pada umumnya. UMKM adalah sebuah usaha untuk membedakan dengan usaha-usaha lain yang berskala besar. Di Indonesia secara konseptual UMKM mempunyai kedudukan istemewa seperti halnya koperasi. Dikatakan istemewa, sebab pelaku UMKM berjumlah sangat banyak. Dalam kesejarahan sangat tahan banting terhadap krisis ekonomi yang pernah terjadi dinegara kita 
(http://ekonomi.kompas.com/read/20

12/03/28) menjadi penupang keberlangsungan ekonomi masyarakat. Singkatnya, UMKM perlu untuk dijaga dan dikembangkan.

Berdasarkan Undang-undang (UU) nomor 20 tahun 2008 tentang Usaha Mikro, Kecil, dan Menengah menjelaskan bahwa tujuannya adalah:

$$
\text { "mewujudkan }
$$

struktur

perekonomian nasional yang seimbang, berkembang, dan berkeadilan; b. menumbuhkan dan mengembangkan kemampuan Usaha Mikro, Kecil, dan Menengah menjadi usaha yang tangguh dan mandiri; dan c. meningkatkan peran Usaha Mikro, Kecil, dan Menengah dalam pembangunan daerah, penciptaan lapangan kerja, pemerataan pendapatan, pertumbuhan ekonomi, dan pengentasan rakyat dari kemiskinan."

$$
\text { Berdasarkan pemaparan }
$$
tersebut, dapat dilakukan penegasan tentang cita-cita besar dari berbangsa dan bernegara. Lebih aplikatif, bisa ditelusuri bahwa bisnis yang dijalankan UMKM lebih kepada pemberdayaan pada satu sisi, dan dalam perkembangannya menjadi unit-unit bisnis dari masyarakat itu sendiri.

B. Bisnis Online

Menurut Timothy $(2010 ; 2-3)$ bisnis online adalah bisnis yang dijalankan dengan menggunakan jaringan internet dalam memasarkan produk atau usahanya. Dengan ada internet, telah menciptakan pasar baru yang berbeda dengan pasar tradisional yang selama ini ada. Maksud dari pengertian diatas adalah bawah keberadaan internet telah menciptakan peluang baru terkiat pemasaran. Dimana sebelumnya, pasar harus merupakan suatau kesatuan yang didasarkan pada tersedianya tempat secara tangable, ketika internet itu ada dan terjejaring dengan baik pasar menjadi intangable.

Dengan tidak mementingkan tempat secara nyata, pasar melalui internet dapat menembus batas-batas 
secara geografis. Dalam pandangan dan praktek bisnis online, pemilik usaha cukup membuka lapak secara virtual saja. Yaitu dengan membuat domain atas produk yang dipasarkan. Pengalaman praktis tentang bisnis online mengalami perkembangan yang luar biasa pesat setelah hubungan pembeli dengan penjual terhubungkan secara langsung. Apalagi setelah muncul era sosial media yang tidak hanya dipergunakan sebagai kegaitan pertemanan tetapi juga sebagai ajang atau tempat promosi barang dan jasa.

\section{Star up}

Pada dasarnya starup merupakan kegiatan bisnis online. Perbedaannya, starup merujuk kepada bisnis online yang telah berhasil. Straup juga merupakan bisa yang berbasis online, dimana pada fase pertumbuhanya mengalami keberhasilan yang cepat dari segi waktu, omset maupun sebaran bisnisnya. Start up juga bisa dengan cepat dibedakan dengan usaha-usaha lain yang berhasil tapi digerakan secara konvensional. Pada akhirnya start up merupakan bisnis yang berbasis online tetapi telah menjadi perusahaan. Startup adalah merujuk pada perusahaan yang belum lama beroperasi. Perusahaan-perusahaan ini sebagian besar merupakan perusahaan yang baru didirikan dan berada dalam fase pengembangan dan penelitian untuk menemukan pasar yang tepat. (https://www.maxmanroe.com/apaitu-startup.html)

Dalam pandangan Graham (2010), startup merupakan perusahaan yang dirancang untuk tumbuh cepat. Perlu dicatat, perusahan yang yang baru didirikan, meskipun mempunyai sifat keterbaharuan baik ide maupun produknya atau produk lama yang didaur luang secara konsep tidak serta merta suatu perusahaan disebut startup. Katagori startup juga bukanlah perusahan teknologi, seperti perusahaan-perusahan komputer atau mengambil dana dari khalayak, yang biasa disebut dana ventura. Ciri pokok start up adalah pertumbuhan bisnisnya, dimana best 
practice-nya memang melalui bisnis yang berbasis internet.(http://www.paulgraham.co m/growth.html)

D. Unicorn

Unicorn sejatinya merupakan istilah untuk perusahan startup. Secara definisi unicorn merujuk kepada perusahaan startup yang sudah maju. Unicorn merupakan katagorisasi startup yang memiliki nilai valuasi lebih dari US\$ 1 miliar.(https://www.wartaekonomi.c o.id/read216051/apa-ituunicorn.html).

Di Indonesia hanya sedikit perusahan startup yang masuk katagori tersebut, diantaranya yaitu PT. Gojek Indonesia, PT. Tokopedia, PT.Treveloka Indonesia dan bukalapak.com. Semua perusahan tersebut merupakan perusahan rintisan yang berdiri di era tahun 2000an. Penting untuk dipahami bahwa keberadaan perusahaan rintisan tersebut dirikan oleh orangorang baru, yang tidak terkait dengan keberhasilan pengusaha yang sukses di masa lalu.

\section{Identifikasi dan Perumusan} Masalah

Dari uraian di atas, muncul pertanyaan sebagai berikut:

a. Bagaimana cara menghadapi tantangan usaha dalam bisnis online, dampak negatif dan kemungkinan peluang yang diperoleh terhadap pelaku UMKM?

b. Bagaimana memperkenalkan pasar online kepada pelaku usaka UMKM?

\section{Tujuan dan Manfaat Program}

Kegiatan pengabdian pada masyarakat ini bertujuan untuk:

a. Memberikan pemahaman kepada pelaku usaha UMKM untuk mengetahui dampak persaingan usaha melalui pemasaran online.

b. Memberikan pelatihan membuat akun di dunia online dalam rangka membuat lapak usaha secara online.

\section{Deskripsi Program}

Secara umum kegiatan ini adalah pemaparan materi dan 
praktek. Kegiatan ini diawali dengan identifikasi persoalan di wilayah intervensi. serta mengumpulkan khalayak sasaran untuk pelaksanaan kegiatan pengabdian.

Secara detail, metode kegiatan sebagai berikut. Pemaparan makalah dengan ceramah dan dialogis, penggunaan viewer, akses intenet. Praktek Pembuatan Akun Bisnis secara Online oleh pelaku UMKM didampingi ahli.

\section{Pelaksanaan Program}

Berdasarkan analisis di lapangan diperoleh gambaran bahwa masih banyak pelaku UMKM mengalami

kemandekan

dalam mengembangkan usahanya. Persoalan-persoalan lama seperti minimanya modal, rendahnya SDM dan mandeknya pemasaran tetap ada. Ini semacam persoalan laten bagi Pelaku UMKM.

Dunia digital yang menjadi arus tak terbendung telah menjadi hegimoni baru bagi peradaban. Hegimoni tersebut juga terjadi di dunia bisnis dengan trackmark bisnis online. Pelaku UMKM secara umum belum familier dengan trackmark tersebut. Banyak pelaku UMKM gamang untuk mengunakan teknologi informasi sebagai basis memajukan usaha mereka. Penyebabnya, rendahnya pengetahuan dan kesadaran pelaku UMKM untuk melibatkan diri kedunia pemasaran online. Akibatnya, banyak usaha UMKM mengalami stagnasi dalam peningkatan penjualan.

Stagnasi usaha UMKM dapat dilihat, pertama Usaha pelaku UMKM tetap hidup tetapi lebih sebatas bertahan hidup, padahal secara umum ratarata melakukan usaha sudah lebih tiga tahun. Kedua, secara umum usaha, pelaku UMKM tidak memperoleh surplus nilai dari usaha 
mereka. Ketiga, secara umum produk usaha UMKM di Jatisari masih jago kandang, alias belum dikenal secara luas oleh konsumen.

Berangkat dari pemahaman di atas, dalam konteks arus informasi yang kecang dan perubahan yang cepat dari dampak dunia digital (internet) termasuk bisnis online menjadi penting untuk mengatasi persoalan pelaku UMKM di desa Jatisari. Pemesahan masalah yang dilakukan, pertama memberikan pengertian tentang bisnis online secara konsep dan ruang lingkupnya dari fenomena dunia digital dan perkembangan warulama. Perkembangan ini meliputi fenonemena bisnis online, bahkan perkembagan stratup dan unicorn.

Kedua, membangun kesadaran. Bahwa arus perubahan yang begitu cepat ini tidak bisa disikapi dengan pasif oleh pelaku UMKM. Lebih jauh, mereka harus terlibat atau mengambil peluang atas arus perubahan yang begitu cepat tersebut. Kesadaran bagi Pelaku usaha UMKM mengambil peran dalam dunia bisnis online merupakan pilihan satusatunya untuk meningkatkan usahanya. Jika mengambil pilihan lain, secara perlawan usaha mereka telah berada difase akhir.

Ketiga, memperkenalkan dengan dunia online khususnya bisnis online. Hal yang mengembirakan dari pelaku usaha UMKM di Desa Jarisari Kecamatan Jenggawa Kabupaten Jember Provinsi Jawa Timur Indonesia, sejatinya mereka termasuk kelompok yang menggunakan internet dan media sosial. Hal tersebut merupakan modal dasar untuk mengenalkan bisnis online secara lebih nyata. Dengan kata, pada fase pemecahan masalah dilakukan pembuatan akun bisnis online sehingga pelaku usaha 
UMKM di desa Jatisari memiliki lapak dalam pasar online.

\section{Khalayak Sasaran}

Kegiatan pengabdian ini diikuti oleh pelaku UMKM yang berada di pedesaan, yaitu Desa Jatisari Kecamatan Jenggawah Kabupaten Jember. Berdasarkan observasi pelaku Usaha UMKM di desa tersebut belum familier dengan dunia internet. Oleh sebab itu mereka berhimpun untuk memperoleh pemahaman dengan tentang bisnis online yang diselenggarakan oleh Dosen Pengabdian masyarakat dengan difasilitasi oleh mahasiswa Kuliah Kerja Nyata (KKN).

Pada akhirnya, pelaku usaha UMKM yang berhimpun tersebut menjadi mitra kerjasama. Para pelaku usaha UMKM yang berhimpun tersebut menamakan diri sebagai Kelompok UMKM Online. Mitra tersebut merupakan khalayak sasaran dari kegiatan pengabdian masyarakat. Mereka secara offline beralamat di Dusun Sukosari RT004 RW013 Desa
Jatisari Kecamatan Jenggawa Kabupaten Jember.

Evaluasi kegiatan difokuskan pada keberhasilan kelompok mitra dalam membuat akun binis secara online. Oleh sebab itu, setiap anggota kelompok mitra melakukan praktek untuk membuat lapak dalam dunia maya melibatkan praktisis bisnis online yaitu bukalapak.com yang berada di Jember. Disamping itu juga melakukan pendampingan kepada anggota kelompok mitra dalam hal mengungga produk mereka ke pasar online. Kedepan, perlu untuk melakukan mendampingan dalam hal melakukan transaksi online secara terus-menerus.

\section{DAFTAR PUSTAKA}

https://dailysocial.id/post/eecommerce-di-indonesia-2018

https://datareportal.com/reports/digit al-2019-indonesia

https://www.wartaekonomi.co.id/rea d216302/pertumbuhan-e-commercepesat di-indonesia.html).

https://www.wartaekonomi.co.id/rea d216051/apa-itu-unicorn.html 
(https://ekonomi.kompas.com/read/2 012/03/28/11093274/Tiga.Hal.yang. Buat.UMKM.Tahan.Krisis)

https://www.maxmanroe.com/apaitu-startup.html

http://www.paulgraham.com/growth. $\underline{\mathrm{html}}$

Undang-undang (UU) nomor 20 tahun 2008 tentang Usaha Mikro, Kecil, dan Menengah

Timothy, James. 2010. Membangun

Bisnis Online. Jakarta.

PT.Elex Media Komputindo 